NOTES

\title{
REGULATION OF INSURANCE ADVERTISING PRACTICES: A JURISDICTIONAL INQUIRY*
}

TEE Supreme Court's holding that the business of insurance is commerce ${ }^{1}$ engendered doubts of the validity of state regulatory legislation, previously the sole means of supervising the industry. ${ }^{2}$ In response, Congress passed the

*American Hospital and Life Ins. Co. v. FTC, 243 F.2d 719 (5th Cir. 1957), cert. granted, 26 U.S.L. WeEk 3147 (U.S. Nov. 12, 1957) (No. 436) ; National Cas. Co. v. FTC, 245 F.2d 883 (6th Cir. 1957), cert. granted, 26 U.S.L. WEEK 3147 (U.S. Nov. 12, 1957) (No. 435).

1. United States v. South-Eastern Underwriters Ass'n, 322 U.S. 533 (1944) (indictment against several fire insurance companies alleging conspiracy to restrain trade in interstate commerce in violation of Sherman Act upheld). South-Eastern Underwriters in effect overruled the holding in Paul v. Virginia, 75 U.S. (8 Wall.) 168, 183 (1869), that the issuance of an insurance policy was not a transaction in commerce. Many case's after Panl had affirmed the proposition that the business of insurance was not commerce. See, e.g., Hooper v. California, 155 U.S. 648 (1895) ; New York Life Ins. Co. v. Cravens, 178 U.S. 389 (1900) ; New York Life Ins. Co. v. Deer Lodge County, 231 U.S. 495 (1913). Since all these cases upheld state statutes in the absence of federal regulation, the Court in South-Eastern Underworiters was able to distinguish them on the ground that none faced the issue whether the commerce clause granted Congress power to regulate interstate insurance transactions. United States v. South-Eastern Underwriters Ass'n, supra at 534, $544-45$.

For comment on South-Eastern Underweriters, see, e.g., Berke, Is the Business of Insurance Commerce?, 42 MrCH. L. Rev. 409 (1943) ; Powell, Instrance as Commerce, 57 HaRv. L. Rev. 937 (1944) ; Notes, 45 Colum. L. Rev. 927 (1945), 20 IND. L. Rev. 184 (1945), 29 Maro. L. Rev. 55 (1945). See also Timberg, Insurance and Intcrstate Commerce, 50 YALE L.J. 959 (1941), which preceded and predicted the result.

On the same day that South-Eastern Underworiters was decided, the Court upheld the application of the National Labor Relations Act to a fraternal association which issued interstate insurance contracts. Polish Nat'1 Alliance v. NLRB, 322 U.S. 643 (1944).

For earlier recognition of the interstate nature of the insurance business, see Hinkler v. Eighty-Three Maiden Lane Corp., 50 F. Supp. 263 (S.D.N.Y. 1943) (dictum) ; Nehemkis, Panl v. Virginia: The Need for Re-examination, 27 Gro. L.J. 519 (1939) (insurance companies had pleaded their interstate character as insulation from state regulation); Berke, A Legal-Economic Discussion of the "S.E.U.A." and "Polish Alliance" Cases, 1944 Ins. L.J. 394, 397-98 (same). See also United States v. South-Eastern Underwriters Ass'n, supra at 592 (listing futile efforts to force congressional control of insurance); Patterson, The Future of State Supervision of Insurance, 23 Texas L. REv. 18, 19 (1944) (Polish Nat'l Alliance and South-Eastem Underworiters "merely tore away an illusory veil from a door that was open all the time"). The prosecution of South-Eastern Underwriters arose because of difficulties encountered by state officials in controlling insurance under state statutes. Joint Hearings Before the Subcommittees of the Committecs on the Judiciary on S. 1362, H.R. 3269, and H.R. 3270, 78th Cong., 1st Sess. 25, 26 (1943) (Attorney General of Missouri appealed for federal intervention).

2. See Sawyer, Insurance as Interstate Commerce 1-4 (1945). Such doubts were basic to Mr. Justice Stone's dissenting opinion in United States v. South-Eastern Under- 
McCarran Act. ${ }^{3}$ Designed to permit continued state control and taxation, ${ }^{4}$ the act also seeks to protect the public interest should state supervision prove inadequate. Thus, the federal antitrust laws-including the Federal Trade Com-

writers Ass'n, supra note 1, at 580-83. The constitutionality of state regulatory statutes depended on whether local control was appropriate and did not unduly burden commerce. Id. at 582. Particularly vulnerable were those statutes discriminating between domestic and foreign insurers or providing for rate-fixing agreements. VANCE, INSURANCE 40-50 (3d ed. 1951).

In a separate opinion, dissenting in part, Mr. Justice Jackson admitted that insurance was commerce in fact but preferred adherence to the historical fiction. In his view, federal regulation should be restricted to direct proscription of activities which burdened interstate commerce. United States v. South-Eastern Underwriters Ass'n, supra note 1, at 584.

Many insurance companies refused to comply with state tax laws since their officers feared civil and criminal sanctions for misappropriation of company funds if these laws were later held unconstitutional. H.R. Rep. No. 143, 79th Cong., 1st Sess. 2 (1945); S. Rep. No. 20, 79th Cong., 1st Sess. 2 (1945) ; 91 Cong. Rec. 478-79 (1945). The situation was described as "absolute chaos" by Senator Ferguson. Id. at 484. And it had been predicted : "If the Court should now decide that insurance is commerce or interstate trade an extremely serious situation would at once arise as the business would then be subject to the Sherman and Clayton Acts with which many of the regulatory laws of the several States, including New Jersey, are in direct conflict. This would create a most deplorable situation, causing a serious disruption in the orderly conduct of this business which is of such vital public interest." Hearings, supra note 1, at 246 (statement by the Commissioner of Banking and Insurance of New Jersey). Contra, id. at 150 (statement by U.S. Assistant Attorney General).

For a discussion of the differences in fundamental theory between state regulatory statutes and the federal antitrust laws, see Gardner, Insurance and the Anti-Trust LawesA Problem in Synthesis, 61 Harv. L. Rev. 246 (1948); 91 Cong. Rec. 479 (1945). For examination of factors affecting the validity of state statutes, see Patterson, supra note 1 , at 27-30; Berke, A Legal-Econonic Discussion of the "S.E.U.A." and "Polish Alliance" Cases, 1944 INs. L.J. 394-95; Harrington, An Exploration of the Effects of the S.E.U.A. Decision, 1944 INs. L.J. 590. Clearly, all state regulation would not have been invalid. See Robertson v. California, 328 U.S. 440 (1946) (California conviction of unlicensed agent of foreign insurance company for acts occurring after South-Eastern Underweriters and before the McCarran Act upheld). The applicability to state statutes authorizing rate fixing in the insurance industry of the ruling in Parker v. Brown, 317 U.S. 341 (1943), that state action is not within the purview of the Sherman Act has not been determined. See North Little Rock Transp. Co. v. Casualty Reciprocal Exchange, 181 F.2d 174 (8th Cir.), cert. denied, 340 U.S. 823 (1950) ; Note, 60 YALE L.J. 160, 163 n.11 (1951).

3. 59 STAT. 33 (1945), as amended, 15 U.S.C. $\$$ 1011-15 (1952).

4. The immediate purpose of the act was to stabilize a chaotic situation. H.R. REP. No. 143, 79th Cong., 1st Sess. 2 (1945) ; S. REP. No. 20, 79th Cong., 1st Sess. 2 (1945). The act declares that continued state regulation and taxation of the insurance business is in the public interest, that congressional silence is not to be construed as barring such regulation or taxation and that the insurance business and persons engaged therein are subject to state laws which relate to the regulation or taxation of the industry.

After South-Eastern Undemuriters, Congress could have either remained silent and allowed case law to establish a dividing line between state and federal jurisdiction, enacted a comprehensive regulatory scheme to be administered by a federal agency or consented to continued state regulation. The McCarran Act, as finally approved, bears no resemblance to bills introduced in 1943 to ward off possible effects of the impending South-Eastern Underworiters decision. These bills precluded applying the Sherman and Clayton Acts to the insurance business. Hearing Before a Subcommittee of the Senate Committee on the 
mission Act-are made applicable to the insurance industry "to the extent that such business is not regulated by state law."5 The jurisdictional demarcation so established has not been effectively crystallized; disagreement exists within

Judiciary on S. 1362, 78th Cong., 1st Sess. 1 (1943). Although the advisability of federal or dual regulation of insurance was discussed at the hearings, the dominant theme of the bills was that the insurance business was traditionally regulated by the states and that such regulation was complete and effective. See Hearings, supra note 1 . The Fouse version, H.R. 3270, 78th Cong., 1st Sess. (1943), passed seventeen days after South-Eastem Underzoriters was decided. 90 CoNG. Rec. 6565 (1944). The Senate version, S. 1362, 78th Cong., 1st Sess. (1943), though reported favorably, Note, Insurance: A Survey of State Rate Regulation, 33 Gro. L.J. 70, 72 (1944), never came to a vote. See Note, 60 Yale L.J. 160,162 (1951). The original version of S. 340, 79th Cong., 1st Sess. (1945), which became the McCarran Act, was a draft prepared by the National Association of Insurance Commissioners. 90 CoNG. Rec. 8482, 9628, A4403 (1944). As reported, this bill expressly made the Federal Trade Commission Act and the Robinson-Patman Act inapplicable to insurance. The NAIC feared FTC pre-emption of the field. Insurance Round Table, 1944 INs. L.J. 716, 718. With the exception of Sherman Act prohibitions against coercion, boycott or intimidation, all other federal antitrust laws were to be inapplicable only to the extent they invalidated, impaired or superseded state laws regulating insurance. 91. Covso. REc. 478-80 (1945). This provision was satisfactory to insurance commissioners and companies. Id. at 479. As the debate indicates, it was also highly ambiguous. Id. at 478-88. Amendment from the floor removed the Sherman and Clayton Acts from the general class of federal laws which were not to invalidate, impair or supersede state laws unless specifically applicable to insurance. $I d$. at 488 . So reading, the bill went to conference, from which it was reported in essentially its present form, see note 5 infra, which was still ambiguous. Compare 91 Cong. REC. 1443 (1945) (Senator Ferguson: legislation alone to -prevent federal regulation), with id. at 1444 (Senator McCarran: only effective state regulation to preclude federal intervention). See Note, 60 Yale L.J. 160, 163 n.11 (1951); Dowling, Insurance Regulation, 5 J. PuB. L. 110, 113 (1956). Debate lasted only two days. 91 CoNG. REC. 1442-44, 1477-89 (1945). The act represents a hasty effort by Congress to allay the confusion caused by South-Eastern Underweriters without estopping future federal control. Id. at 1487.

5. 59 STAT. 34 (1945), as amended, 15 U.S.C. \$ 1012 (1952) : "(b) No Act of Congress shall be construed to invalidate, impair, or supersede any law enacted by any State for the purpose of regulating the business of insurance, or which imposes a fee or tax upon such business, unless such Act specifically relates to the business of insurance: Provided, That after June 30,1948 ... the Sherman Act . . the Clayton Act . . . the Federal Trade Commission Act ... shall be applicable to the business of insurance to the extent that such business is not regulated by State law."

The act also provided that the Sherman, Clayton, FTC, and Robinson-Patman Acts should not apply to any aspects of the insurance business until after the expiration of a three-year moratorium. 59 STAT. 34 (1945), as amended, 15 U.S.C. $\$ 1013$ (1952). This moratorium was intended to allow the states to adjust their regulatory programs. 91 Cona. REC. 1442 (1945).

The Sherman Act, however, was expressly made applicable "to any agreement to boycott, coerce, or intimidate, or act of boycott, coercion, or intimidation." 59 STAT. 34 (1945), 15 U.S.C. $\$ 1013$ (b) (1952); see United States v. New Orleans Ins. Exchange, 148 F. Supp. 915 (E.D. La.), aff'd per curiam, 78 Sup. Ct. 96 (1957) (group boycott affecting interstate commerce violated Sherman Act). See also Spiegle v. Board of Fire Underwriters, 29 Cal. 2d 34, 172 P.2d 867 (1946) (California Cartwright Act does not confict with Sherman Act and is applicable to boycotts and coercions in either interstate or intrastate insurance). 
the Federal Trade Commission ${ }^{6}$ as well as between the Commission and the courts. ${ }^{7}$ Although the obvious public interest in insurance practices suggests that adequacy of supervision be a prime consideration in adjusting the roles of federal and state authorities, the extent and efficacy of control has been generally ignored by both the FTC and the courts. ${ }^{8}$

All members of the Federal Trade Commission postulate constitutionai limitations on the power of a state to regulate interstate insurance within its borders. A majority restricts state jurisdiction derived from the McCarran Act to transactions which are in interstate commerce only because of their effect upon other transactions conducted directly across state boundaries. ${ }^{9}$ Presumably predicated on cases denying Congress the power to delegate legislative authority, ${ }^{10}$ this position overlooks qualifications permitting congressional consent to state legislation where a significant value in national uniformity is absent. ${ }^{11}$ While Congress clearly could have established an extensive regula-

6. See, e.g., American Hospital and Life Ins. Co., CCH Trade Reg. Rep. 1956-57 Transfer Binder $\uparrow 25954$ (FTC 1956) ; National Cas. Co., CCH TRADE REg. REP. 1956-57 Transfer Binder If 26010 (FTC 1956); North Am. Acc. Ins. Co., CCH Trade Reg. Rep. 1956-57 Transfer Binder \ 26396 (FTC Feb. 20, 1957) ; Federal Life and Cas. Co., CCH TRADE REg. Rep. 1956-57 Transfer Binder đ 25997 (FTC 1956).

7. American Hospital and Life Ins. Co. v. FTC, 243 F.2d 719 (5th Cir. 1957), reversing CCH TRADE REG. REP. 1956-57 Transfer Binder I 25954 (FTC 1956); National Cas. Co. v. FTC, 245 F.2d 883 (6th Cir. 1957), reversing CCH Trade Reg. Rep. 1956-57 Transfer Binder If 26010 (FTC 1956).

8. See notes $9,16,17,22$ infra.

9. American Hospital and Life Ins. Co., CCH TRAdE REg. Rep. 1956-57 Transfer Binder If 25954 (FTC 1956).

The FTC does not have jurisdiction over matters merely affecting interstate commerce. Commission power depends on actual activity in interstate commerce. See FTC v. Bunte Bros., Inc., 312 U.S. 349 (1941) ; Note, The Regulation of Advertising, 56 CoLun. L. REv. 1018, 1023 (1956). However, most insurance business in the United States falls within this category. See United States v. South-Eastern Underwriters Ass'n, 322 U.S. 533, 599-43 (1944).

10. See Brief for Complaining Counsel, p. 4, American Hospital and Life Ins. Co., CCH TRADE REG. REP. 1956-57 Transfer Binder If 25954 (FTC 1956), relying on In re Rahrer, 140 U.S. 545, 560 (1891) ("Congress can neither delegate its own powers nor enlarge those of a State"), and Knickerbocker Ice Co. v. Stewart, 253 U.S. 149, 164 (1920) ("Congress cannot transfer its legislative power to the States-by nature this is non-delegable"). See also American Hospital and Life Ins. Co., supra at 35842. However, Rahrer held that Congress could adopt state law if competent to regulate in the area. And the basis of Knickerbocker Ice was the need for national uniformity in admiralty. See also Clark Distilling Co. v. Western Md. Ry., 242 U.S. 311, 327 (1917) (Webb-Kenyon Act divesting liquor of its interstate character held constitutional); Hanover Nat'l Bank v. Moyses, 186 U.S. 181, 190 (1902) (federal bankruptcy law recognizes exemptions granted by local law).

In structure, the McCarran Act is similar to the Act of Aug. 7, 1789, c. 9, § 4, 1 Stat. 54, which declared that pilots should be regulated by state laws enacted for that purpose. See Cooley v. Board of Wardens, 53 U.S. (12 How.) 298 (1851) (upholding 1803 Pennsylvania law regulating pilots since subject matter did not require uniform, exclusive federal regulation).

11. Prudential Ins. Co. v. Benjamin, 328 U.S. 408 (1946) (upholding constitutionality of the McCarran Act), is the leading exposition of the "consent theory" which validates 
tory system instead of passing the McCarran Act, ${ }^{12}$ uniformity of control over the insurance industry has been held unnecessary. ${ }^{13}$ Moreover, the Commission's jurisdictional determination contradicts its own view that the act was designed to restore state regulation to the position it occupied before insurance was declared commerce. ${ }^{14}$ Prior to that declaration, each state supervised all insurance activities occurring within its borders. ${ }^{15}$ The Commission minority,

federal legislation permitting state laws to operate in sectors of interstate commerce otherwise barred to them by the Constitution. Although its constitutional basis has never been explained by the Court, the theory is firmly established. See Dowling, Intcrstate Commerce and State Power-Revised Version, 47 CoLuM. L. Rev. 547, 552-60 (1947) (criticizing rationalization in Pntdential Ins. Co.); Dowling, Congress and Instrance, $5 \mathrm{~J}$. PuB. L. 110 (1956). See also Note, Congressional Consent to Discriminatory State Legislation, 45 Colum. L. Rev. 927 (1945). See also Southern Pac. Co. v. Arizona ex rel. Sullivan, 325 U.S. 761,769 (1945) (dictum) ; International Shoe Co. v. Washington, 326 U.S. 310, 315 (1945).

The McCarran Act is not a delegation of power by Congress, Prudential Ins. Co. v. Benjamin, supra at 439-40, nor an affirmative exercise of the legislative power described in Clark Distilling and In re Rahrer, id. at 438. It is not an adoption of state law, ibid., but an exercise of the power to consent, in effect freeing state control of insurance from any commerce clause inhibitions. See, generally, Mermin, "Cooperative Federalism" Again: State and Municipal Legislation Penalizing Violation of Existing and Future Federal Requirements: $I, 57$ YALE L.J. 1, 24-25 n.61 (1947).

12. The power of Congress over interstate commerce is "complete in itself, may be exercised to its utmost extent, and acknowledges no limitations, orher [sic] than are prescribed in the constitution." Gibbons v. Ogden, 22 U.S. (9 Wheat.) 1, 196 (1824). Restraints on the exercise of this power "must proceed from political rather than from judicial processes." Wickard v. Filburn, 317 U.S. 111, 120 (1942). Sonth-Eastem Underwitcrs constitutes judicial recognition of congressional power to assume full control of "interstate" insurance. For evidence that Congress so understood the case, see 91 CoNG. Rec. 478 passim (1945).

13. Prudential Ins. Co. v. Benjamin, 328 U.S. 408, 431-33 (1946). The Court approved a finding that "the McCarran Act is, in effect, a determination by Congress that the business of insurance, though done in interstate commerce, is not of such a character as to require uniformity of treatment within the distinction taken in the doctrine of Cooley "? Board of Wardens ...." Id. at 431 n.39. See Delaney, The Future of State Regulation of Insurance, 1950 Ins. L.J. 402. But see Sawyer, Insurance as Interstate Commerce 7-8 (1945).

14. "[T] he McCarran-Ferguson Act was designed to permit the States to regulate, in the traditional manner, the business of insurance." American Hospital and Life Ins. Co., CCH TRADE Reg. Rep. 1956-57 Transfer Binder \ 25954, at 35839 (FTC 1956).

15. Only the jurisdictional aspects of due process restricted state regulation of insurance prior to South-Eastern Underwriters. Prudential Ins. Co. v. Benjamin, 328 U.S. 408, 416 \& n.14 (1946). Thus, a state could regulate the activities of a foreign corporation only to the extent they occurred within its borders. St. Louis Cotton Compress Co. v. Arkansas, 260 U.S. 346 (1922). See Connecticut Gen. Life Ins. Co. v. Johnson, 303 U.S. 77 (1938) (California not permitted to tax reinsurance contracts entered into in Connecticut on policies originally made in California); Allgeyer v. Louisiana, 165 U.S. 578 (1897) (contract made in New York cannot be governed by Louisiana law). The McCarran Act was not intended to change the rule of these cases. H.R. REP. No. 143, 79th Cong., 1st Sess. 3 (1945). But see, generally, on the lower standards which have recently been required by substantive due process, Hoopeston Canning Co. v. Cullen, 318 U.S. 313 (1943) (insured's state has 
envisaging a "flow of commerce" over which the states have no prerogative and in which Congress would be constitutionally disabled from delegation, ${ }^{16}$ uses reasoning similar to that of the majority to define a narrower area of federal jurisdiction. ${ }^{17}$

Recent efforts by the FTC to control advertising practices of health and accident insurance companies have provoked two circuit courts into definitive resolution of the jurisdictional lines between national and state instrumentalities. Many health and accident companies advertise primarily by brochures mailed from home offices either directly to consumers or to agents for transmission to consumers. The FTC ordered several such companies to cease and desist from circulating false and misleading advertising in interstate commerce. ${ }^{18}$ The Fifth Circuit, in American Hospital and Life Ins. Co. v. FTC, ${ }^{19}$ and the Sixth Circuit, in National Cas. Co.v. FTC, ${ }^{20}$ denied the Commission's authority to issue the orders on substantially identical grounds. Each rejected the constitutional limitations imposed on state authority by the Commission. ${ }^{21}$ Construing the act's denial of federal control over insurance prac-

recognizable interest in the contract); Osborn v. Ozlin, 310 U.S. 53 (1940) (resident agent statute does not violate due process); Dowling, Congress and Insurance, $5 \mathrm{~J}$. PuB. L. 110, 111 (1956); Dowling, Interstate Connerce and State Power-Revised Version, 47 Colun. L. KEv. 547, 550-51 (1947).

16. See American Hospital and Life Ins. Co., CCH Trade REg. Rep. 1956-57 Transfer Binder If 25954, at 35846 (FTC 1956).

17. The "flow" encompasses mail-order insurance transmitted directly from a company in one state to consumers in another, see Travelers Health Ass'n, CCH TRADE REg. REP. 1956-57 Transfer Binder \26327, at 36114 (FTC 1956) (concurring opinion), but not that transmitted first to agents, American Hospital and Life Ins. Co., supra note 16. It may also include interstate television and radio advertising. See Federal Life and Cas. Co., CCH Trade REg. Rep. 1956-57 Transfer Binder $\{25997$ (FTC 1956) (dissenting opinion). See also North American Acc. Ins. Co., CCH Trade Reg. Rep. 1956-57 Transfer Binder II 26396, at 36154 (FTC Feb. 20, 1957) (dissenting opinion). But see, Note, The Regulation of Advertising, 56 Coluar. L. REv. 1018, 1076 (1956).

18. Complaints were originally issued against 41 companies, including the largest health and accident insurers. American Hospital and Life Ins. Co., CCH TRADE REg. RFP. 1956-57 Transfer Binder $\{25954$ (FTC 1956). A recent count indicates that the Commission has issued final orders in 14 cases, 6 of which were stipulations to consent, see note 48 infra. In 18 completed proceedings before hearing examiners, 13 initial decisions to cease and desist and 5 dismissals were ordered. The 41 complaints were the result of 2,800 investigations. See Commissioner Gwynne, quoted in McConnell, State Regulation v. State Regulation plus Regulation by Multiple, Decentralized, Independent Federal Agencies, 1956 INs. L.J. 697, 701. For background on these complaints, see Fraizer, Federal Trade Commission Jurisdiction?, 22 Ins. Counser J. 467 (1955) ; McAlevey, Present Status of State Regulation of the Accident and Health Business, 1956 INs. L.J. 39.

19. 243 F.2d 719 (5th Cir. 1957), cert. granted, 26 U.S.L. WeEk 3147 (U.S. Nov. 12, 1957) (No. 436).

20. 245 F.2d 883 (6th Cir. 1957), cert. granted, 26 U.S.L. WeEK 3147 (U.S. Nov. 12, 1957) (No. 435).

21. 243 F.2d at $724 ; 245$ F.2d at 886. Only the Fifth Circuit admitted the possibility of an area of interstate insurance necessarily restricted to federal jurisdiction. See 243 F.2d at 724 . 
tices regulated by the states, both courts considered state regulation synonymous with state legislation. ${ }^{22}$ This rationale offers an easy formula for solution of jurisdictional conflicts. The sovereign authorized to regulate any particular of the insurance business can be determined by reference to state statutes; if state law covers the practice concerned, state jurisdiction is exclusive.

Since individuals injured by misleading insurance advertising cannot secure adequate compensation, meaningful protection against such practices depends upon preventive government sanctions. ${ }^{23}$ Material deception most frequently occurs with respect to noncancelability and effective dates of policies, extent or duration of coverage or benefits payable, and applicant's health requirements. ${ }^{24}$ Misleading statements disseminated to the public through a variety of media are relied upon by consumers lacking access to sample policies prior to purchase. ${ }^{25}$ Moreover, the average policy is so complex that consumers are unlikely to detect material differences between its provisions and the simple, intelligible advertising which induces the sale. ${ }^{26}$ Consequently, in most instances the consumer's first hint of a discrepancy between his actual and supposed coverage does not occur until he suffers sickness or injury and the company refuses to pay his claim. Restitution of premiums paid may not cover the loss suffered, ${ }^{27}$ and reformation of the contract to conform with advertising relied

22. $243 \mathrm{~F} .2 \mathrm{~d}$ at $723 ; 245 \mathrm{~F} .2 \mathrm{~d}$ at 888 .

23. The function of the FTC is preventive rather than punitive or remedial. FTC v. Gratz, 253 U.S. 421 (1920); 51 CoNG. ReC. 11455 (1914).

24. The questioned practices are set forth in the FTC cease and desist orders cited in note 6 supra. See also McCarter, Recent Missleading and Deceptive Mail-Order Accident and Health Insurance Policies and Advertising, 23 Ins. Counsex J. 82, 84-86 (1956); note 26 infra.

25. American Hospital and Life Ins. Co., CCH TrADE Reg. Rep. 1956-57 Transfer Binder I 25954, at 35844 (FTC 1956) ; McCarter, supra note 24, at 84. Misleading advertisements are not cured by truthful representations to the buyer before purchase. Carter Products, Inc. v. FTC, 186 F.2d 821 (7th Cir. 1951) ; Fairyfoot Products Co. v. FTC, 80 F.2d 684 (7th Cir. 1935). See also note 26 infra.

26. Under the Federal Trade Commission Act, the standard of public sophistication used to measure "deception" is less than that of the reasonable man. FTC v. Standard Educ. Soc'y, 302 U.S. 112 (1937). And, on the strength of language in Standard Education which apparently brands a false advertisement as necessarily misleading, id. at 116 , the courts have moved to even wider protection. See, e.g., Stork Restaurant v. Sahati, 166 F.2d 348, 358-59 (9th Cir. 1948) ; Parker Pen Co. v. FTC, 159 F.2d 509, 511 (7th Cir. 1946) ; General Motors Corp. v. FTC, 114 F.2d 33, 36 (2d Cir. 1940). See also United States v. Sylvanus, 192 F.2d 96, 105 (7th Cir. 1951), cert. denied, 342 U.S. 943 (1952) : "It goes without saying almost that it is extremely difficult for a layman to understand the terms and conditions of such policies as these . . ."But see Moretrench Corp. v. FTC, 127 F.2d 792, 795 (2d Cir. 1942) ; Rosenblum v. FTC, 214 F.2d 338 (2d Cir. 1954).

27. Recision and restitution has been held a proper remedy for an insured whose expectations are unrealized due to representations, innocent or otherwise, by the insurer. Herman v. Mutual Life Ins. Co., 108 F.2d 678, 679-80 (3d Cir. 1939). See Hogben v. Metropolitan Life Ins. Co., 69 Conn. 503, 38 At1. 214 (1897) ; Beckwith v. Ryan, 66 Conn. 589, 34 Atl. 488 (1895); New Era Life Ass'n v. Weigle, 128 Pa. 577, 18 Atl. 393 (1899). 
upon is unlikely. ${ }^{28}$ In addition, even if the requisite intent could be proved, a tort action for misrepresentation may lie only against the agents perpetrating the deceit and hence be no more successful than they are solvent. ${ }^{29}$

Although the public interest requires effective government prohibition of deceptive insurance advertising, measures adopted by the states are inadequate. Violations of cease and desist orders issued by state regulatory agencies pursuant to fair trade practices acts-enacted in a majority of states ${ }^{30}$-often involve inconsequential penalties. ${ }^{31}$ Administrative machinery established to supervise the insurance business within a state is frequently so limited that no significant attention can be given to advertising practices. ${ }^{32}$ Even adequately

28. Mutual Benefit Life Ins. Co. v. Ruse, S Ga. 534 (1850); Fowler v. Metropolitan Life Ins. Co., 1.16 N.Y. 389, 22 N.E. 576 (1889); Ruse v. Mutual Benefit Life Ins. Co., 23 N.Y. 516 (1861) ; Vance, Insurance 236 (2d ed. 1930). But see Southern Mut. Life Ins. Co. v. Montague, $84 \mathrm{Ky} .653,2$ S.W. 443 (1887).

29. Insurance contracts typically provide that the application and the policy constitute the entire contract between the parties and that no agent is authorized to alter or amend their terms. Patterson, Cases on Insurance 806 (3d ed. 1955). See Peters v. Colonial Life Ins. Co., $128 \mathrm{~Pa}$. Super. 21, 193 Atl. 460 (1937) (limitations on agents' authority in policies effective) ; Maddox v. Life \& Cas. Ins. Co., 79 Ga. App. 164, 53 S.E.2d 235 (1949) (same). But see Vance, Insurance 449 (2d ed. 1930).

30. In addition to the 38 states which have enacted the Model Trade Practices Act, see note 54 infra, the following states prohibit misrepresentation of policy terms: AlA. Code tit. 28, § 26 (Supp. 1955) ; CAL. Ins. Code \$\$ 780-84, 1731 ; Idago Code ANN. § 411012 (Supp. 1957) ; Ill. Rev. Stat. c. 73, § 761 (1957) ; Mo. Ann. Stat. § 561.660 (Supp. 1957) ; Mont. Rev. Codes ANn. $\$ \$ 40-1939$, 40-1941, 40-1942 (Supp. 1957) ; ORE. Rev. Stat. $\$ \S 736.608,737.550$ (1955) ; Wask. REv. CodE $\$ \S 48.30 .010,48.30 .040$ (Supp. 1957).

31. Compare, e.g., ARK. Stat. ANN. § 66-1711 (Supp. 1955) (penalty for violation not to exceed $\$ 50$; if violation willful, penalty not to exceed $\$ 500$ ); Conn. GeN. STar. $\S 2820 d$ (Supp. 1955) (same) ; Iowa CoDE ANv. \$ 507B.11 (Supp. 1956) (same); Me. Rev. Stat. Ann. c. 60, § 156 (Supp. 1957) (same); S.C. Code § 37-1221 (Supp. 1955) (same), writh 38 STAT. 719 (1914), as amended, 15 U.S.C. $\$ 45(l)$ (1952) (penalty for each violation of FTC cease and desist order not to exceed $\$ 5,000$; if violation continuous, $\$ 5,000$ for each day of duration). But see, e.g., Miss. CoDE ANn. \$ 5649-11 (Supp. 1957) (insurer's license to do business may be revoked or suspended in addition to or in lieu of maximum fine of $\$ 1,000$ ); N.J. STAT. ANN. $\S 17: 29 \mathrm{~B}-11$ (Supp. 1956) (penalty not to exceed $\$ 5,000$ for each violation). See also statutory authorization to enjoin violation, e.g., Ariz. Code Ann. § 61.1411(b) (Supp. 1954); Ky. Rev. Stat. Ann. § 304.023 (1955); WASH. Rev. CoDE $\$ 48.02 .080$ (3) (Supp. 1957); 43 C.J.S., Injunctions $\$ 150$ (1945). On general provisions for license suspension or revocation, see, e.g., Conn. GEN. STat. $\S 2786 d$ (Supp. 1955) ; Del. Code ANN. tit. 18, $\$ 329$ (Supp. 1956) ; Ky. Rev. Stat. ANN. § 304.091 (1955); La. Rev. Stat. Ann. $\$ 22: 1457$ (Supp. 1956); Micr. Stat. AnN. $\$ 24.12064$ (1957) ; W. VA. Code ANN. $\$ 3303$ (Supp. 1957) ; Wis. Stat. $§ 200.14$ (1955).

32. In Delaware, for example, the statute staffs the department entrusted with full responsibility for supervision of the insurance industry with two executives, two clerks and one actuary. Ded. Code ANn. tit. 18, \$§ 307, 309-11 (Supp. 1956). See also GA. Code AnN. \$ 56-101 (Supp. 1955) (Comptroller General serves as Insurance Commissioner and may appoint a deputy).

Department effectiveness may be further limited by outside pressures. See, e.g., Hearings, supra note 1, at 108-09 (powerful insurance lobbies exert strong influence on state 
staffed state insurance departments are often handicapped by constricting administrative techniques. The New York department, for example, acts solely on a complaint basis; no continuous or recurring investigations of advertising practices are undertaken. ${ }^{33}$

These shortcomings are compounded by jurisdictional limitations on state control. Maximum protection is afforded consumers dealing with insurance companies incorporated by states which prohibit unauthorized foreign sales. ${ }^{34}$ Even these consumers, however, find their state with limited capacity to protect them from deceptive mail-order advertising and sales. ${ }^{35}$ Terminating the local authority of an offending foreign company may bring about revocation of that company's domestic authority to sell within the offended state's borders. But absent further action by the domestic state, continued advertising and selling

regulation) ; Patterson, supra note 1, at 30-37 (discussion of needed reforms in state insurance departments after passage of the McCarran Act). High personnel turnover in state insurance departments also impedes effective regulation. See N.Y. State Insurance Commissioner Dine'en, The Rating Problem, in Procerdings of the Section of Insurance Law, AMrerican Bar Association 105-06 (1945).

In addition to supervising insurance advertising practices, state regulatory schemes generally require the administrator to process licensing of companies and agents, audit annual statements, collect premium taxes and approve policy forms. Fraizer, supra note 18.

33. 1. New York State Insurance Departarent, Examination of Insurance ConPanres 11, 32-65 (Straub ed. 1953). "If the State of New York with its vast resources and its immense Insurance Department cannot and does not regulate the unfair or deceptive acts or practices of insurers who owe their very corporate life to it, it can scarcely be expected that the lesser States in the constellation of the Union can accomplish anything by similar acts and powers." Commercial Travelers Mut. Acc. Ass'n, 3 CCH TRADE Reg. REP. I 26553 (FTC June 20, 1957) (initial decision). See United States v. Sylvanus, 192 F.2d 96, 104 (7th Cir. 1951), cert. denied, 342 U.S. 943 (1952) (general ineffectiveness of Illinois Insurance Department).

The FTC regularly inspects commercial announcements and representations and investigates those of a suspicious nature. Geller, Advertising AT the Crossroads 163-66 (1952). But see, Donovan, State Regulation of Insurance, 1956 INs. L.J. 11, 14 (FTC worse than the worst state insurance department). Donovan was formerly counsel for the National Bureau of Casualty Underwriters. See Donovan, Regulation of Instrance Under the McCarran Act, 15 Law \& Contenr. ProB. 473 (1950).

34. See Colo. Rev. Stat. Ans. § 72-1-40 (Supp. 1955); Idaho Code Ann. § 41-109 (Supp. 1957) ; Kan. Gen. Stat. Ann. \$ 40-214 (1949); Mont. Rev. Codes Ann. \$\$ 401314 to -1317 (Supp. 1957) ; N.M. Stat. ANN. \$ 58-4-9 (Supp. 1957); OHIo Rev. Cone $\$ 3905.44$ (Anderson Supp. 1956) ; ORE. Rev. STAT. \$ 736.645 (1955) ; S.D. CoDE $\$ 31.1104-1$ (Supp. 1952); UtaA Code ANN. \& 31-7-9 (Supp. 1957). See also Conn. Gen. Stat. $\S 2816 \mathrm{~d}$ (Supp. 1955) (foreign unfair trade practices).

Some states prohibit domestic companies from engaging in unauthorized foreign business only when the foreign state has enacted reciprocal legislation. See CAL. INS. CodE § 706.7; Fla. Stat. Ann. \$§ 625.38-40 (Supp. 1956) ; Ky. Rev. Stat. Ann. § 304.585 (1955); La. Rev. Stat. Ann. § $22: 1251$ (Supp. 1956); Md. Ann. Code art. 48A, § 195 (Supp. 1957) ; N.H. Rev. Stat. ANN. c. 402, § 54 (Supp. 1955) ; N.D. Rev. Code \$ 26-0719 (Supp. 1949); WASH. REv. CODE $\$ 48.07 .150$ (Supp. 1957).

35. The business done by mail-order insurers is considerable. See McCarter, supra note 24 , at 86 (the annual premiums paid mail-order companies for health and accident policies estimated to be $\$ 67,500,000$ ) . 
by mail to the citizens of the offended state is possible. The offended state cannot enforce penal sanctions upon an absent defendant, ${ }^{36}$ nor can it require a state with power over the defendant to take such action. ${ }^{37}$ Clearly, state supervision thus geared to the degree of co-operation which can be invoked from foreign sovereigns is a control medium of limited utility. ${ }^{38}$ And, since the majority of states do not proscribe unauthorized foreign business, even optimum co-operation would yield minimal regulation. ${ }^{39}$

The American Hospital and National Casualty construction of the McCar$\operatorname{ran}$ Act-equating legislation to regulation ${ }^{40}$-fosters inadequate supervision of the insurance industry. State enforcement machinery, lagging behind its statutory framework ${ }^{41}$ and circumscribed by territorial limitations, leaves a void area not reached in fact by the states and into which the FTC cannot enter. ${ }^{42}$ Nevertheless, some federal control of deceptive insurance advertising

36. In Travelers Health Ass'n v. Virginia, 339 U.S. 643 (1950), the State Corporation Commission had ordered the Association, a mail-order health insurer from Nebraska without tangible assets in Virginia and unlicensed to operate there, to cease and desist from further offerings or sales in Virginia until it complied with the state blue-sky law. The Court held that the cease and desist order based upon substituted service did not violate due process. However, no indication was given of means by which the Commission might enforce its order. Both injunction and fine appear futile since no agents or property exist within the state. The Uniform Unauthorized Insurers Act, permitting substituted service on unauthorized insurers on suits on policies, has been adopted in most states. See McGee v. International Life Ins. Co., 26 U.S.L. WEEK 4073 (U.S. Dec. 16, 1957), reversing 288 S.W.2d 579 (Tex. Civ. App. 1956) (judgment obtained under California version of uniform act entitled to full faith and credit). However, these statutes only apply to suits on policies and are not regulatory. See Travelers Health Ass'n, supra at 653 (concurring opinion). In one state, substituted service is statutorily authorized in a regulatory context. N.D. Laws 1951, c. 188. While cease and desist orders may thus be obtained against "absent" insurers, the problem of enforcement remains.

37. See Note, Reaching the Out-Of-State Mail-Order Insurer, 64 HARv. L. REv. 482 (1951) ; Comment, Unlicensed Foreign Insurance Companies: The Jurisdiction and Enforcement Problems, 17 Mo. L. Rev. 73 (1952). But see ifcCarter, supra note 24, at 90;

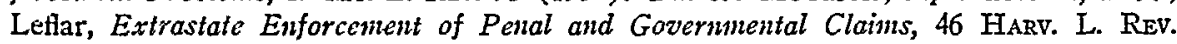
193 (1932); Comment, 25 U. CHI. L. REv. 187 (1957).

38. See Travelers Health Ass'n, CCH TRADE REg. REP. 1956-57 Transfer Binder $\llbracket 26327$, at 36114 (FTC 1956) (concurring opinion). But see Patterson, supra note 1, at $37-38$.

39. When an insurer is not domiciled and incorporated in the same state, co-operation may also be solicited from the state of domicile. However, only Nebraska proscribes unfair foreign practices of domiciled insurers. Neb. Laws 1957, c. 191, § 2, amending NEB. Rev. Stat. $\$$ 44-1503 (Supp. 1953).

40. See note 22 supra and accompanying text.

41. See notes 32,33 supra and accompanying text. Some companies have even requested stricter state enforcement policies. McCarter, supra note 24, at 102.

42. A possible remedy might be for the states to make mail solicitation within their borders by unauthorized insurers unlawful and for Congress to make use of the mails in violation of these statutes a federal offense. Cf. Note, Reaching the Ont-Of-State MailOrder Insturer, 64 HaRv. L. REv. 482,489 (1951) ; Rhodes v. Iowa, 170 U.S. 412 (1898); Note, Congressional Consent to Discriminatory State Legislation, 45 CoLux. L. Rev. 927, 935 (1945). 
may be exercised by the Justice and Post Office Departments without infringing on state prerogatives under the McCarran Act. Since post office fraud orders ${ }^{43}$ and prosecutions for criminal mail fraud ${ }^{44}$ are unlikely to invalidate, impair or supersede state insurance laws, ${ }^{45}$ they may be directed against members of the industry..$^{46}$ But both of these enforcement measures require proof of intent to defraud as well as the dissemination of a misleading statement and thus may not reach the whole range of objectionable practices. ${ }^{47}$ Furthermore,

43. 26 Stat. 466 (1890), as amended, 39 U.S.C. \$ 259 (1952) (Postmaster General may, upon evidence satisfying him that a person is making false or fraudulent representations in the conduct of a scheme or device through the mails, mark "Fraudulent" and return to the sender all mail addressed to that person).

The fraud order was early held to apply to commercial advertisements. Harris v. Rosenberger, 145 Fed. 449, 458 (8th Cir. 1906). See Note, The Regulation of Advertising, 56 CoLUM. L. REv. 1018, 1042 (1956) (collecting cases). When no longer satisfied that a person is violating the mail fraud statute, the Postmaster General has a duty to revokenot merely suspend-the mail fraud order. New Orleans Nat'l Bank v. Merchant, 18 Fed. 841. (C.C.E.D. La. 1884). Intent is determined by the Postmaster General. 26 STAT. 466 (1890), as amended, 39 U.S.C. $\$ 259$ (1952). But the determination is reversible upon a showing of abuse of discretion. Leach v. Carlile, 258 U.S. 138, 139-40 (1922) ; Cates v. Haderlein, 189 F.2d 369, 373 (7th Cir. 1951).

The Post Office Department has a stipulation procedure similar to that of the FTC. Attorney General's Committee on Administrative Procedure, Administrative Procedure in Government Agencies, S. Doc. No. 186, 76th Cong., 3d Sess., pt. 12, at 16-17 (1940). See note 48 infra.

44. 62 Stat. 763 (1948), as amended, 18 U.S.C. $\$ 1341$ (1952). The elements of the criminal and mail fraud statutes are similar. Atlanta Corp. v. Olesen, 124 F. Supp. 482, 484 (S.D. Cal. 1954). Nevertheless, since the latter is administrative and preventive, while the former is criminal and punitive, significant differences exist in their application. See Sanden v. Morgan, 225 Fed. 266 (S.D.N.Y. 1915) ; cf. Harrison v. United States, 200 Fed. 662, 667-69 (6th Cir. 1912). The government must prove guilt beyond a reasonable doubt to sustain a criminal charge. In judicial review of fraud orders, on the other hand, the burden is on the defendant to show that the Postmaster General has abused his discretion. Sanden v. Morgan, supra at 268-89. See note 43 supra.

Criminal prosecutions are seldom brought in the advertising area because of the severity of the sanction and the difficulty of establishing the requisite intent to defraud. Note, The Regulation of Advertising, 56 CoLUM. L. Rev. 1018, 1041 \& $\mathrm{n.133}$ (1956).

45. See text at note 51. infra.

46. See United States v. Sylvanus, 192 F.2d 96 (1951), cert. denied, 342 U.S. 943 (1952). Sylvanus, a criminal mail fraud conviction for misrepresentation in insurance advertising, held the McCarran Act inapplicable and state insurance regulation irrelevant. Since the McCarran Act does not except mail statutes from its purview, see 59 STAт. 34 (1945), as amended, 15 U.S.C. $\$ 1012$ (1952), note 5 supra, such acts appear applicable to insurance advertising unless construed to invalidate, supersede or impair state laws regulating the industry. The mail statutes require proof of intent to deceive in addition to the fact of misrepresentation, see note 47 infra, and thus do not appear to conflict with state supervision exercised through unfair trade practices acts. However, should the mail statutes be construed contrary to Sylvamus, the McCarran Act would insulate insurance advertising from their reach.

47. Reilly v. Pinkus, 338 U.S. 269, 276-77 (1949) (mail fraud). United States v. Sylvanus, supra note 46, at 108-09 (criminal sanction); accord, Hawley v. United States, 133 F.2d 966, 972 (10th Cir. 1943) (good faith a defense); Post v. United States, 135 Fed. 
neither department is organized to patrol advertising material, and each lacks the valuable experience of the FTC in the field. ${ }^{48}$

Adequate supervision of insurance advertising is, therefore, dependent upon a construction of the McCarran Act giving the FTC jurisdiction wherever

1,9 (5th Cir. 1905). See Note, The Regulation of Advertising, 56 CoLun. L. Rev. 1018, 1040 (1956) (collecting cases). Intent to deceive is not prerequisite to an FTC cease and desist order, since its purpose is consumer protection and a misleading statement is not cured by the absence of an intent to defraud. FT.C v. Algoma Lumber Co, 291 U.S. 67 (1934) ; D. D. D. Corp. v. FTC, 125 F.2d 679, 682 (7th Cir. 1942).

Under both mail statutes and the Federal Trade Commission Act, whether someone is in fact defrauded is immaterial if the mails are used in furtherance of a scheme to deceive. United States v. Sylvanus, supra note 46, at 105-06; Charles of the Ritz Distributors Corp. v. FTC, 143 F.2d 676, 680 (2d Cir. 1944); Baker v. United States, 115 F.2d 533 (8th Cir. 1940), cert. denied, 312 U.S. 692 (1941). But mail fraud may require that the representations have a tendency to deceive. Jeffries v. Olesen, $121 \mathrm{~F}$. Supp. 463, 472 (S.D. Cal. 1954). And the FTC can act only where such a tendency exists. E.g., S. Buchsbaum \& Co. v. FTC, 160 F.2d 121 (7th Cir. 1947) ; D. D. D. Corp. v. FTC, supra at 682; Gimbel Bros., Inc. v. FTC, 116 F.2d 578 (2d Cir. 1941). See Atlanta Corp. v. Olesen, 124 F. Supp. 482 (S.D. Cal. 1954) (proof of an incorrect statement or misrepresentation is not sufficient to prove a violation).

48. The FTC can enjoin false advertising which either establishes an unfair method of competition or is a deceptive practice. Federal Trade Commission Act, 38 STAT. 719 (1914), as amended, 15 U.S.C. $\$ \$ 45$ (a) (1), (b) (1952). The main function of the Commission has long been to control advertising. See Note, The Regulation of Advertising, 56 Colum. L. Rev. 1018, 1022 n.26 (1956). The Commission has developed a stipulation procedure by which the advertiser consents to cease and desist from condemned practices without the expenditure of money and time required by a formal proceeding. Id. at 103435. This informal method of control is not a final order. 38 STAT. 719 (1914), as amended, 15 U.S.C. $\$ 45(\mathrm{~g})$ (1952). Therefore, a violation is not penalized under 38 STAT. 719 (1914), as amended, 15 U.S.C. $\$ 45$ (l) (1952), see note 31 supra. A consent order, even if observed, is not a bar to further proceedings. See Rock v. FTC, 117 F.2d 680 (7th Cir. 1941). The Stipulation for Consent Order has been used extensively by the Commission in its campaign against health and accident insurance practices. See note 18 supra.

One federal court has suggested that the mail fraud statutes be used only when a clear scheme to defraud exists; otherwise, the matter should be handled by an agency experienced in regulating. Pinkus v. Walker, 61 F. Supp. 610 (D.N.J. 1945), modified, 338 U.S. 269 (19.19). The FCC also is a potential regulator of advertising through its broad licensing power. 48 STAT. 1083 (1934), 47 U.S.C. $\$ 307$ (1952) (criterion for granting or renewing a broadcasting license is whether issuance will further "public interest, convenience, and necessity"). The commission sanction operates directly against the broadcaster. However, it may have an indirect effect upon an advertiser and has been used for this purpose. See, e.g., Farmers \& Bankers Life Ins. Co., 2 F.C.C. 455 (1936) ; WSBC, Inc., 2 F.C.C. 293 (1936) ; Ben S. McGlashan, 2 F.C.C. 145 (1935). As a matter of policy, advertising complaints are referred to the FTC. Attorney General's Committee on Administrative Procedure, Administrative Procedure in Government Agencies, S. Doc. No. 186, 76th Cong., 3d Sess., pt. 3, at 40 (1940).

See also 18 U.S.C. $\$ 1343$ (1952) (provision similar to the mail fraud statute making fraud by wire, radio or television a criminal offense). However, this statute has been used only to convict for a fraudulent scheme carried out by telegram. Wiltsey v. United States, 222 F.2d 600 (4th Cir. 1955). See Esquire Inc. v. Walker, 151. F.2d 49, 55 (1945), aff'd sub nom. Hannegan v. Esquire Inc., 327 U.S. 146 (1946): "We believe that the Post Office Officials should experience a feeling of relief if they are limited to the more prosaic 
state regulation is ineffective. Not only does the act bear such a construction, it suggests a congressional intent to require more than legislation from the states if federal control is to be prohibited. ${ }^{40}$ If regulation and legislation were considered equivalent, the express proviso making federal antitrust law applicable to insurance to the extent the industry is not "regulated" by the states would be functionless. 50 The section of the act containing the proviso also prohibits construing federal statutes to invalidate, impair or supersede state "laws" enacted to regulate insurance. 51 This prohibition would itself be sufficient to preclude federal intervention through the FTC if state legislation alone were intended as the test. Addition of the proviso, explicitly referring to the Fed-

function of seeing to it that 'neither snow nor rain nor heat nor gloom of night stays these couriers from the swift completion of their appointed rounds.'"

Moreover, since regulation of advertising by a rigid set of rules is not feasible, a method of control similar to the Trade Practice Conference of the FTC may be desirable. See Fraizer, supra note 18. To employ this voluntary conference method effectively, a nationwide conference to promulgate rules by the FTC, see Nature of Trade Practice Rules, 3 CCH TRADE REg. REP. If 20002 (FTC 1955), rather than a separate conference in each of the states, is necessary. In 1950, the FTC promulgated rules with respect to mail-order insurance, but these were later repealed. 3 CCH TRADE REG. REP. I 20187 (FTC 1956). More recently, the Commission established rules governing health and accident insurance. Trade Practice Conference Rules, Accident and Health Ins. Industry, 3 CCH TRAde Reg. Rep. If 20029 (FTC 1956). These rules are a guide to the industry, and violations are not sanctioned as such. Note, The Regulation of Advertising, 56 Colum. L. REv. 1018, 1083 (1956).

49. "[T] Congress proposes by this bill to secure adequate regulation and control of the insurance business." H.R. ReP. No. 143, 79th Cong., 1st Sess. 2 (1945) ; S. REP. No. 20, 79th Cong., 1st Sess. 2 (1945). See also 90 Cong. Rec. A3120 (1944) (effective state regulation protecting the interests of a policyholder the best means to avoid federal regulation). Congress was aware of the inadequacies of state regulation. See, e.g., Hcarings, supra note 1 , at $55,80,81,142,168,181$. The need for reform was also recognized by the National Association of Insurance Commissioners. See Orfield, Improzing State Regulation of Insurance, 32 MinN. L. Rev. 219, 230-61 (1948). For the position that regulate means actual control in the public interest and not merely legislation, see N.Y. Insurance Superintendent Dineen, The Rating Problem, in Procendngs of Tre Sectron of Insurance Law, American Bar Associarion 104, 109 (1945) ("To regulate means to regulate-not to go through the motions"), and authorities there cited: 91 CoNG. REc. 1478-80, 1488 (1945); White House Release, March 10, 1945 (statement by President Roosevelt upon signing the McCarran Act, quoted in Donovan, Regulation of Insurance Under the McCarran Act, 15 LAw \& Contenc. ProB. 473, 478 (1950)) : "[T] he antitrust laws ... will be applicable ... to the business of insurance except to the extent that the states have assumed the responsibility, and are effectively performing that responsibility, for the regulation of whatever aspect of the insurance business may be involved." Thomerson, Federal Trade Commission Surveys State Insurance Laws, 1950 Iivs. L.J. 333, 33536, and authorities cited. But see, McCarran, Federal Control of Insurance: Mforatorium Under Public Law 15 Exsired July 1, 34 A.B.A.J. 539, 542 (1948) : "The inquiry will be: 'Is this practice regulated by State law?'-not 'Is it effectively regulated?',

50. See 57 STar. 34 (1945), as amended, 15 U.S.C. $\$ 1012$ (1952), note 5 supra.

51. See ibid. Conceivably, the section has effect only with respect to statutes passed under the commerce clause. 91 CoNG. Rec. $481-83$ (1945). But sce United States v. Sylvanus, 192 F.2d 96 (7th Cir. 1951), cert. denied, 342 U.S. 943 (1952) ; 91 CuNG. Rec. 479 (1945) (section applicable to all past and future federal laws). 
eral Trade Commission Act, indicates that "regulated" is a term of broader compass than "laws," that effective implementation is as important as regulatory policy. ${ }^{\mathrm{t}}$

Evaluation of a given state's control should accordingly be founded upon both the conceptual and actual reach of the sovereign's regulatory legislation. In light of the Supreme Court's recent recognition that the McCarran Act does not affect the FTC's power to investigate in order to establish the bounds of its power to regulate, ${ }^{53}$ the Commission will be free to make this evaluation. Once it determines that a state's regulation is satisfactory, it should not challenge questionable activities which are not proscribed by state law. Although the Model Unfair Trade Practices Act, enacted in thirty-eight states, ${ }^{54}$ closely

52. See note 49 supra. See also Note, 60 Y ALE L.J. 160 (1951), criticizing North Little Rock Transp. Co. v. Casualty Reciprocal Exchange, 181 F.2d 174 (8th Cir.), cert. denicd, 340 U.S. 823 (1950), which held that the mere existence of a state statute concerning the setting of insurance rates was sufficient to defeat a suit under the Sherman Act. The note suggests that, to fulfill the purpose of the McCarran Act, rate-making re'gulation must provide for and be implemented by affirmative administrative action in order to preclude the applicability of federal antitrust statutes. See also SAwYER, INsurance as Interstate Commerce 78-82 (1945); Travelers Health Ass'n, CCH Trade REg. REp. 1956-57 Transfer Binder If 26327, at 36114 (FTC 1956) (concurring opinion); Dineen, supra note 49, at 109.

53. FTC v. Crafts, 78 Sup. Ct. 33 (1957), reversing per cutriam 244 F.2d 882 (9th Cir. 1957). The Supreme Court did not write an opinion and only cited Oklahoma Press Publishing Co. v. Walling, 327 U.S. 186 (1946), and Endicott Johnson Corp. v. Perkins, 317 U.S. 501 (1943), each of which held that the district court in normal circumstances was not a proper body to determine the extent of an agency's investigative jurisdiction. But if the position of the Fifth and Sixth Circuits, supra note 22, were correct, the district court might have taken judicial notice that the FTC was without jurisdiction on the basis of the McCarran Act and refused to enforce the subpoena. Oklahoma Press Publishing Co. v. Walling, supra (dictum; "coverage" may be determined by district court if investigation plainly irrelevant to agency's lawful purpose); Endicott Johnson Corp. v. Perkins, supra (dictum; same). See 48 Star. 291 (1933), 15 U.S.C. \$ 46(a) (1952) (power of the Commission to investigate practices of corporations engaged in commerce); Gilmore, Govemment and the Insurance Business, 1950 INs. L.J. 408, 408-09 (regardless of the degree of state supervision, the McCarran Act does not exclude the FTC from exercising power to investigate).

54. With some variations, the model act has been enacted in the following states: Ariz. Code ANn. $\$ \S 61-3301$ to -3318 (Supp. 1954) ; Ark. Stat. Ann. $\$ \S 66-1701$ to -1713 (Supp. 1957) ; Colo. Rev. Stat. Ann. \$\$ 72-15-1 to -13 (Supp. 1955); Conn. Gen. STat. $\S \S 2816 d-21$ d (Supp. 1955) ; DeL. Code Awn. tit. 18, $\S 531-38$ (Supp. 1956) ; Fla. Stat. ANs. $\$ \S 643.01-.13$ (Supp. 1956) ; GA. Code ANN. $\$ \$ 56-401$ a to -413a (Supp. 1955) ; IND. Ann. Stat. \$\$ 39-5301 to -5318 (1955); Iowa Code Ann. \$\$ 507B.1-B.13 (Supp. 1956) ; Kan. Gen. Stat. Ann. $\$ \$ 40-2401$ to -2414 (Supp. 1953) ; Ky. Rev. Stat. Ann. $\$ \S 304.924-945,304.990$ (1955) ; LA. Rev. Stat. Anv. $\$ \S 22: 1211-: 1217,22: 1455$ (Supp. 1956) ; Me. Rev. Stat. Ann. c. 60, $\$ 146-58$ (Supp. 1957) ; Md. Ann. Code art. 48A, $\S \S 321-35$ (Supp. 1957) ; MAss. ANN. Laws c. 176D, \$§ 1-14 (Supp. 1956) ; Mrch. STAt. ANn. $\S \S 24.12001-.12050$ (1957); Mrnn. Stat. Ann. \$§ 72.20-.33 (Supp. 1956); Miss. Code Ann. $\$ \$ 5649-01$ to -12 (Supp. 1957) ; Neb. Rev. Stat. $\$ \$ 44-1501$ to -1521 (Supp. 1953), as amended, Neb. Laws 1957, c. 191; Nev. REv. Stat. chapters $686.390-470$ (1956) ; N.H. Rev. Stat. AnN. c. 417, \$\$ 1-17 (Supp. 1955) ; N.J. Stat. Ann. \$§ $17: 29 \mathrm{~B}-1$ 
resembles FTC proscriptions, ${ }^{55}$ borderline violations of either scheme might not be condemned by the other. Should these occasions arise, the McCarran Act dictates the supremacy of state criteria. ${ }^{56}$

to -14 (Supp. 1956) ; N.M. Stat. Ann. \$\$ 58-9-9 to -19 (Supp. 1957) ; N.Y. INs. Law $\$ \S 270-82$; N.C. Gen. Stat. $\$ \$ 58-54.1-.13$ (Supp. 1957) ; N.D. Laws 1957, c. 204; OHIo Rev. Code $\$ \$ 3901.19-23,3923.16$ (Anderson Supp. 1956) ; Orna. Stat. Ann. tit. 36, $\$ \S$ 117.1-14 (Supp. 1956) ; PA. Stat. Ann. tit. 40, $\S 1151-62$ (Supp. 1956) ; S.C. CoDE \$§ 37.1201-.1223 (Supp. 1955); S.D. CoDE \$§ 31.11A01-08, 31.9934 (Supp. 1952); TENN. Code Ann. \$\$ 56-1201 to -1213 (Supp. 1957) ; UTAн Code Ann. \$\$ 31-27-1 to -9 (Supp. 1957) ; Vt. Acts 1955, c. 174; VA. Code ANn. $\$ \$ 38.1-49$ to -57 (Supp. 1956) ; W. VA. CODE Ann. $\$ \$ 3472(8)-(22)$, 3331 (Supp. 1957) ; WIs. Stat. \$\$ 207.01-.13 (1955); Wyo. CoMr. Stat. Ann. $\$ \$ 52-1501$ to -1512 (Supp. 1957).

55. See McCarter, sitpra note 24 , at $89-90 ; 4$ New York State Insurance Department, Examination of Insurance Companies 51-53 (Straub ed. 1954); Thomerson, suppra note 49 , at $340-41$.

56. See 91 Cong. Rec. 1478, 1481 (1945). 